COMPETITOR: Jurnal Pendidikan Kepelatihan Olahraga

Volume 13 Number 1 Year 2021

e-ISSN: 2657-0734 \& p-ISSN: 2085-5389

This work is licensed under a Creative Commons Attribution 4.0 International License

\title{
Impact of Covid-19 Pandemic on Organization of Professional Football League In Nigeria
}

\author{
Memunat Tunrayo Ajadi ${ }^{i^{*}}$, Abdulraheem Yinus Owolabi ${ }^{2}$, Falaye Elijah Kayode ${ }^{3}$ \\ ${ }_{1,2,3}$ University of Ilorin / Ilorin / Nigeria \\ 1,2,3 No C2, Studiopedia, Off Ministry of Health, Fate Tanke Rd, behind Lgea Primary School, Ilorin, Nigeria \\ ${ }^{1}$ sampayoo2014@gmail.com, ${ }^{1}$ mtajadi2014@gmail.com
}

Received: December 30, 2020; Reviewed: January 11, 2021; Accepted: January 24, 2021;

Published: February 27, 2021

\begin{abstract}
Football is one of the major sports that contribute to the economic and social development of a community which requires effective organization. However, this study examined impact of COVID-19 on the organization of professional football league in Nigeria. The objectives of this study were to: assess the relationship between a postponement of league and pay cut of wages of players on the organization of football league. The descriptive research design of survey type was used. The population comprised all registered players and sports administrators. A stratified and purposive sampling technique was used to select 100 respondents. Researcher-structured questionnaires were employed. The validity and reliability level of the instrument was through test re-test method using Pearson Product Moment Correlation (PPMC) and a co-efficient of 0.85r was obtained. The administration of the instrument was done by the researchers and research assistants. The data collected were analyzed using Pearson Product Moment Correlation. The result of the findings revealed that there was a significant relationship between a postponement of league and pay cut of wages and organization of professional football league in Nigeria. The study concluded that the league management and NFF should meet with other stakeholders to brainstorm the modalities on the resumption of the league in Nigeria.
\end{abstract}

Keywords: COVID-19 pandemic; Impact; Professional football league; Organization.

\section{INTRODUCTION}

Globally football is one of the major sports that promote economic and social development, its role is well recognized by the international communities in the political declaration of 2030 agenda which reflects on the contribution of sports especially football and other sports to the empowerment of youth across the world. (Daniela, Melissa, Carol \& Robert 2020). However, the organization of the football league globally has been considered a valuable tool for fostering communication and building bridges between communities and generations.

The foundation of professional football clubs is one of the social groups that play a significant role in the economy and social transformation of a community. Ever since the 
Impact of Covid-19 Pandemic on Organization of Professional Football League In Nigeria

MEMUNAT Tunrayo Ajadi ${ }^{*}$, ABDULRAHEEM Yunus Owolabi ${ }^{2}$, FALAYE Elijah Kayode ${ }^{3}$

sampayoo2014@gmail.com

COVID-19 pandemic broke out in December 2019, in Wuhan province of china, the world has not been the same again with disruption in all spheres of human endeavor including sports.

COVID-19 pandemic has been considered a relative of a severe acute respiratory syndrome (SARS) which has the possibility of transfusion from animals to humans (Yingfe \& Zhena, 2020). The biggest sporting casualty this year is the 2020 summer Olympics scheduled for Tokyo, Japan that was earlier scheduled to hold from July 24 to August 9, 2020, has been postponed till the next year 2021, due to the ravaging of the COVID-19 pandemic.

Furthermore, the Olympic games are the largest sports gathering in the world and it is the most-watched event with millions of people in the world and billions of dollars are often generated from sponsorships and television rights (Stevens, \& Prins 2020).

The global value of the sports industry is estimated at $\$ 756$ billion annually which $70 \%$ of this estimated money is generated from football competition across the globe. In Africa, virtually all football competitions including the league such as the CAF champions league, the African cup of Nations, the 2022 world cup qualifiers for men and women, and the confederation cup all have been shifted to later dates this year or postponed till next year due to COVID-19 pandemic. Similarly, top European countries such as Spanish Laliga, Italia Serie A, French League, English Premier League, German Bundesliga football league are all on hold due to the ravaging effects of the COVID-19 pandemic. (Southcombo, 2020).

In Nigeria, the Nigeria professional league and National sports festival which is held biennially and by all standards the biggest sporting event in the country have all been put on hold due to the outbreak of COVID-19lockdown (Sunday 2020) As a result of this, every other sporting activities in the country including the Nigeria Premier league have been adversely affected by COVID-19. Also, most of the professional football clubs at the top of the league table are eyeing domestic glory of getting a continental ticket to represent the country at the prestigious CAF competitions while teams at bottom of the table are battling to escape from the relegation zone and teams from the lower division are also struggling to gain promotion into Nigeria Premier league but their fates are hanging in the balance due to the Coronavirus pandemic for 2019/2020 season.

This has put the ambition of Kwara United football club that is struggling to escape relegation and Abubakar Bukola Saraki football club that is aiming at gaining promotion into the elite league on hold. On March 28th, 2020, the League Management Company 
Impact of Covid-19 Pandemic on Organization of Professional Football League In Nigeria

MEMUNAT Tunrayo Ajadi ${ }^{1 *}$, ABDULRAHEEM Yunus Owolabi ${ }^{2}$, FALAYE Elijah Kayode ${ }^{3}$

sampayoo2014@gmail.com

(LMC) the organizers of the (NPFL) announced the suspension of the Nigeria top flight until further notice after its week 25 matches across the country in a bid to comply with the governments directive in line with precautionary measures against COVID-19. Around the world, some league calendars are already been canceled due to protocol guidelines that were prescribed by the health workers to prevent the spread of COVID-19 with total lockdowns syndrome, curfews, and strict social distance rules were put in place to keep people safe (World Health Organization, 2020) To safeguard the health of the players and others stakeholders that are involved in the organization and administration of the professional football league, the league management company had to announce the cancellation/postponement of the league till further notice (www.goal.com 2020).

Also, the global response has prompted the total shutdown of competitive sports at all levels. This shutdown includes multiple postponements of mega-events such as Olympics games, European champion league, a confederation of African Football competitions, and other leagues in the world (Parnell, Widdop Bond \& Wilsen, 2020).

In the face of the COVID-19 pandemic professional footballers, both home and abroad have been taken limited pay cuts typically $20-50 \%$ of their salary due to the suspension of their league. This is a result of the fact that football players are consistently wealthy enough to adapt to the situation without feeling it on their jobs and this has made some club owners approached the governments for financial support to cover the waged of their players and other staff (France 24, 2020).

The global outbreak of the COVID-19 pandemic has resulted in the closure of sports facilities to be used by the players/athletes to stop the spread of these contagious infections. The closure of gymnasiums and stadium have denied many people from participating actively in their daily exercise outside their homes due to COVID-19. Under these conditions, many tend to be less physically active and lose of physical fitness of football players. (Daniela et al 2020). However, lockdown may have hindered the development of football leagues in Nigeria and beyond.

\section{Statement of the Problems}

The structural changes of sporting activities as a result of the COVID-19 pandemic has led to delay, postponement, and cancellation of various leagues across the world. For instance, some football players believe that the suspension or postponement of the league is a threat and barrier to their career progression in football. The researchers observed that in the face of the COVID-19 pandemic, sports disruption, the government directives on the closure of sports facilities have also hindered the team's training which has 
affected the fitness level of all football players. The wages of the players were also placed on pay-cuts ration such that some club owner in the league and even the government own football clubs has to pay these players on a percentage of 30 to $50 \%$ especially the professional football clubs in the study area while some clubs are even owning their player's salary for months. This among other reasons spurred the researchers to investigate the impact of the COVID-19 pandemic on the organization of professional football league in Nigeria.

\section{Hypotheses}

The following research hypotheses were formulated and tested for the study

1. There is no significant relationship between postponements of the league and the organization of professional football clubs in Nigeria.

2. There is no significant relationship between the closure of sports facilities and the organization of professional football leagues in Nigeria.

3. There is no significant relationship between pay cut of wages and organization of professional football league in Nigeria.

\section{Objectives of the Study}

The objective of this study was specifically meant to:

1. Examine the impact of postponement of the league on the organization of professional football clubs in Nigeria.

2. Investigates the impact of the closure of sports facilities on the organization of professional football leagues in Nigeria.

3. Determine the impact of pay-cut wages on the organization of professional football leagues in Nigeria.

\section{METHOD}

A descriptive research design of survey type was employed for the study. The population of the study comprised all sports administrators and players of both Kwara United and Abubakar Bukola Saraki football clubs. Stratified and purposive sampling techniques were used to select 100 respondents for the study. A stratified sampling technique was used to group the respondents into two strata of club managements and registered football players in the league. Purposively all the 20 sports management staff and 64 registered football players for the 2019/2020 season of teams were sampled. Also, 16 executive members of the Football Association (FA) were purposively sampled. The 
researcher's structured questionnaire was used for the study. The instrument was validated by three lecturers in the Department of Human Kinetics Education, University of Ilorin, and the Director of Sports Kwara State Sports Council. The reliability of the instrument was established through the test re-test method using Pearson Product Moment Correlation (PPMC). A correlation coefficient of 0.85 was obtained. The instrument was administered by the researchers and four trained research assistants. The data collected were analyzed using inferential statistics of Pearson Product Moment Correlation (PPMC) to test the formulated hypothesis set for the study at 0.05 alpha level.

\section{RESULTS AND DISCUSSION}

\section{Results}

Hypothesis one: There is no significant relationship between a postponement of the league and the organization of professional football clubs in Nigeria.

Table 1

Revealed Correlation Analysis " $r$ " of Postponement of the League and Organization of Professional Football Clubs.

\begin{tabular}{lccccccc}
\multicolumn{1}{c}{ Variables } & N & Mean & SD & df & $\begin{array}{c}\text { Cal } \\
\text { r-value }\end{array}$ & Sig & Remark \\
\hline $\begin{array}{l}\text { Postponement of the } \\
\text { league }\end{array}$ & & 20.12 & 2.223 & & & & \\
$\begin{array}{l}\text { Postponement of the } \\
\text { league }\end{array}$ & 100 & 20.12 & 2.436 & 98 & 0.505 & 0.000 & $\begin{array}{l}\text { Hypothesis } \\
\text { Rejected }\end{array}$ \\
\begin{tabular}{l}
$\mathrm{P}<0.05$ \\
\hline
\end{tabular} & & & & & & &
\end{tabular}

Table 1 shows the calculated r-value of 0.505 and critical r-value of 0.00 with 98 degrees of freedom at 0.05 alpha level. Since the calculated r-value is greater than the critical r-value hence the null hypothesis that stated that there is no significant relationship between a postponement of the league and organization of professional football clubs in Nigeria was hereby rejected. This implies that there was a significant relationship between the postponement of the league and the organization of professional football clubs in Nigeria.

Hypothesis two: There is no significant relationship between the closure of sports facilities and the organization of professional football league in Nigeria. 


\section{Table 2}

Indicated Correlation Analysis ' $r$ ' of Closure of Sports Facilities and Organization of Professional Football League.

\begin{tabular}{|c|c|c|c|c|c|c|c|}
\hline Variables & $\mathbf{N}$ & Mean & SD & df & $\underset{\text { r-value }}{\text { Cal }}$ & Sig & Remark \\
\hline Closure of Sports facilities & & 13.15 & 2.11 & & & & \\
\hline $\begin{array}{l}\text { Organization of } \\
\text { Professional Football league }\end{array}$ & 100 & 15.32 & 2.34 & 98 & 0.602 & 0.000 & $\begin{array}{l}\text { Hypothesis } \\
\text { Rejected }\end{array}$ \\
\hline
\end{tabular}

$\mathrm{P}<0.05$

Table 2 revealed the calculated r-value of 0.602 against the critical r-value of 0.00 with 98 degrees of freedom at 0.05 alpha level. Since the calculated r-value is greater than the critical r-value, therefore, the null hypothesis that stated that there is no significant relationship between the closure of sports facilities and the organization of professional football leagues in Nigeria was hereby rejected. This means that there was a significant relationship between the closure of sports facilities and the organization of professional football leagues in Nigeria.

Hypothesis Three: There is no significant relationship between pay cut of wages and organization of professional football league in Nigeria.

Table 3

Shows Correlation Analysis "r" of Pay Cut of Wages and Organization of Professional Football League.

\begin{tabular}{|c|c|c|c|c|c|c|c|}
\hline Variables & $\mathbf{N}$ & Mean & SD & df & $\begin{array}{c}\text { Cal } \\
\text { r-value }\end{array}$ & Sig & Remark \\
\hline Pay cut of wages & & 18.25 & 1.76 & & & & \\
\hline Professional Football League & 100 & 16.41 & 2.59 & 98 & 0.723 & 0.000 & $\begin{array}{l}\text { Hypothesis } \\
\text { Rejected }\end{array}$ \\
\hline
\end{tabular}

$\mathrm{P}<0.05$

Table 3 indicated the calculated r-value of 0.723 and critical $r$-value of 0.00 with 98 degrees of freedom at 0.05 alpha level since the calculated r-value is greater than the critical p-value hence, the null hypothesis that stated that there is no significant relationship between pay cut of wages and organization of professional football league in Nigeria was hereby rejected. This implies that there was a significant relationship between put cut of wages and organization of professional football league in Nigeria.

\section{Discussions of the findings}

The finding from tested hypothesis one revealed that there was a significant relationship between a postponement of the league and the organization of professional 
Impact of Covid-19 Pandemic on Organization of Professional Football League In Nigeria

MEMUNAT Tunrayo Ajadi ${ }^{1 *}$, ABDULRAHEEM Yunus Owolabi ${ }^{2}$, FALAYE Elijah Kayode ${ }^{3}$

sampayoo2014@gmail.com

football leagues in the study area. This study supported the findings of Parnell, Widdop, Bond \& Willson (2020) that stated that the total lockdown which includes the multiple postponements of mega-events such as the European champions league, a confederation of African football competitions, and other sporting event poses a threat on the organization of football league across the globe and this also influences the fitness level of individual players. Similarly, www.goal.com (2020) stressed that around the world some league calendars are already been concluded such as the French league due to protocol guidelines prescribed by the Health workers to prevent the spread of the COVID-19 pandemic.

The finding from tested hypothesis two revealed that there was a significant relationship between the closure of sports facilities and the organization of professional football leagues in the study area. This result is in line with the views of Sunday (2020) who stressed that the closure of sports facilities around the world due to the COVID-19 pandemic hurts sports development in the last few weeks. This also hindered the training program of football teams on daily basis and as such the suspension of the football league may also be linked to the closure of sports facilities across the world. Also, Daniela et al (2020) affirmed that the closure of gymnasiums and stadium have denied many people including the players from participating actively in their daily exercise, also under this conditions which could also affect their fitness level.

The finding from tested hypothesis three indicated that there was a significant relationship between pay cut of wages and organization of professional football league in the study area. This result buttresses the findings of France 24 (2020) who affirmed that in the face of COVID-19Pandemic professional footballers both home and abroad have been taken limited pay cut typically $20-50 \%$ of their salary due to the suspension of their league. This is as a result of the fact that football players are consistently wealthy enough to adapt to the ugly situation during lockdown without feeling in their purse. In the same vein Southcombe (2020) concluded that in some cases, many of the non-paying staff has lost their job and players were placed on pay cut wages on percentage while some club owners have approached the government for financial supports to pay wages of their players and other staff in the clubs.

\section{CONCLUSIONS AND SUGGESTIONS}

\section{Conclusion}


Based on the findings of the study the researchers concluded that there was a significant relationship between a postponement of the football league and the organization of professional football clubs, there was also a significant relationship between the closure of sports facilities and the organization of professional football league and there was a significant relationship between pays cut of wages and organization of professional football league in Nigeria.

\section{Suggestions}

The study, therefore, suggested that both the League Management Company (LMC) and Nigeria Football Federation (NFF) should meet with the presidential task force on COVID-19 set up by the federal government and brainstorms the modalities for the early resumption of the suspended football league. Also, periodic COVID-19 tests should be conducted for all players and sports administrators in the league likewise the COVID-19 guideline protocol should be observed such as the use of nose masks and the use of hand sanitizer must be strictly adhered to. All matches should be played closed door.

\section{REFERENCES}

Adams, B. E, Joana, B, Paddy, D, Josef, F, Remco, H, Verena, L, Gareth Mc, Maureen, S \& Laura W. (2020). Sports in the face of the COVID-19 pandemic - towards an agenda for research in the sociology of sports. European Journal for Sports and Society. 17 (2) 85-95.

Daniela, B, Mellissa, M, Carol, P, \& Robert, V. (2020). The Impact of COVID-19 on Sports, physical activity and well being and its effects on social development. Department of Economic and Social affairs. www.un.org/development/desa/publications.

France 24. (2020). Townsend hits out at UK health minister for blaming footballers. Retrieved April 15, 2020 from https:///www.france.com/en/20200403

Parnell, D, Duiddop, P, Band, A \& Wilson, R (2020). COVID-19, networks and sports managing sports and leisure, 1-7. https://doi.org

Southcombe, M. (2020). Joe maler won't miss a game despite long ban for grabbing Alun wyn jones tesicles as secret six nations meeting emerges - Retrieved April 28, 2020 from https://www.walesonline.com.uk/sports/rugbynews.

Stevens, v\&prins, R-G. (2020). Twitters sentiments towards the COVID-19 responses of the F.A, UEFA and IOC. Retrieved April 24, (2020) from https://www.mulurinstitut. nilpublicates/2534/twitters-sentiments towards COVID-19 responses of the UEFA. 
Sunday, D. (2020). The professional football league and National sports festival by all standards, the biggest sporting event in the country have all been put on hold due to the outbreak of COVID-19. Press released by Honourable Minister of Youth and Sports development.

World Health Organization. (2020). WHO warns against Corona Virus immunity passports. Guardian United Nation.

Zheng, F \& Yingfie, Z. (2020). Impact of the COVID-19 Pandemic on mental Health and Quality of life among local residents in Liaoning province, china. A cross sectional resident, public health. 177 (7). https://www.goal.com(2020) closure of all sports facilities in the country as a result of COVID-19 pandemic. Retrieved $10^{\text {th }} \mathrm{June}$, 2020. 